\title{
AUDIT KOMUNIKASI ORGANISASI WAHANA LINGKUNGAN HIDUP INDONESIA (WALHI) YOGYAKARTA
}

\author{
Dian Ramadani, Puji Lestari, dan M. Edy Susilo \\ Prodi Ilmu Komunikasi, FISIP UPN “Veteran” Yogyakarta, Jl. Babarsari No. 2 Yogyakarta, \\ No. Telp. 0274-485268, fax. 0274-487-147 \\ Email : pujilestariupn@gmail.com
}

\begin{abstract}
The paper aims to analyze process of communication audit in WALHI Yogyakarta organization to increase organization systems to improve organization effectiveness using information of organization theory and qualitative descriptive method. The research found that the process of implementation communication audit of organization in WALHI Yogyakarta works quite well as demonstrated by the five units of analysis: organization, content of information, management of organization, communication processes or activities of communication, and feedback. Of the five unit of analysis it is found that openness factor vertically or horizontally has a big role in improving the performance of an organization's success. Another factor is the role of communication technology to simplify and accelerate the delivery of information internally. Media written or printed or electronic media is used in support of this organization. Communication audit implemented in every organization will improve the performance of organization.
\end{abstract}

Keywords : Communication Audit, Horizontal-Vertical Communication, Communication Media

\begin{abstract}
Abstrak
Penelitian ini bertujuan menganalisis proses pelaksanaan audit komunikasi organisasi pada Organisasi WALHI Yogyakarta terhadap peningkatan sistem organisasi untuk meningkatkan efektivitas organisasi. Penelitian ini menggunakan teori informasi organisasi dan metode deskriptif kualitatif. Temuan penelitian ini menggambarkan proses pelaksanaan audit komunikasi organisasi WALHI Yogyakarta sudah berjalan cukup baik. Hal ini ditunjukkan oleh lima unit analisis yaitu organisasi, muatan informasi, manajemen, proses komunikasi atau kegiatan-kegiatan komunikasi, dan umpanbalik. Dari kelima unit analisis tersebut ditemukan faktor keterbukaan secara vertikal maupun horizontal mempunyai peran yang sangat besar dalam meningkatkan keberhasilan kinerja organisasi. Faktor lain yang memengaruhi adalah peran teknologi komunikasi untuk memudahkan dan mempercepat penyampaian informasi secara internal. Media-media tertulis, cetak, maupun elektronik merupakan media penunjang yang digunakan dalam organisasi ini. Audit Komunikasi yang diterapkan di setiap organisasi akan meningkatkan kinerja organisasi tersebut.
\end{abstract}

Kata Kunci : Audit Komunikasi, Komunikasi Vertikal-Horizontal, Media Komunikasi

\section{Pendahuluan}

Hak menyangkut kebebasan informasi pada mulanya mulai muncul seiring dengan keberhasilan reformasi yang menumbangkan rezim totaliter Soeharto kala itu, dimulai dengan rumusan ketetapan MPR Nomor: XVII/ MPR/1998 yang mengatur tentang Hak Asasi Manusia. Pada pasal 21 dan 22 dari ketetapam ini menyebutkan secara spesifik tentang kebebasan informasi.
Rumusan ini selanjutnya diadopsi ke dalam UUD 1945 dalam sidang amandemen tahap 2 yang disahkan pada 18 Agustus 2000 yang tertuang dalam pasal $28 \mathrm{f}$.

Kebebasan informasi di negeri ini, merupakan hak dasar rakyat yang harus dipenuhi oleh Negara. Pentingnya kebebasan memperoleh informasi dalam kehidupan bernegara merupakan suatu keniscayaan, karena hal tersebut akan memberikan dampak positif dalam hal 
pelaksanaan proses bernegara, disamping itu akan memberikan kontribusi besar kepada pelaksana negara dalam hal mempercepat terwujudnya negara hukum yang demokratis. (http:/ / pemerintah.net/keterbukaan-informasipublik-pemerintah/, tanggal akses 30 September 2014)

Demi menjaga keberlangsungan Bumi tempat makhluk hidup berada, manusia harus bersama melakukan pelestarian lingkungan hidup. Sebelum membahas jauh tentang pelestarian, maripelajari dahulu beberapa istilah seperti pengertian lingkungan hidup, kerusakan lingkungan, dan sebagainya.

Sebagai upaya untuk menyelamatkan lingkungan diperlukan ketepatan dan koordinasi yang baik antar eksekutif daerah maupun dewan daerah terkait dalam melaksanakan sistem komunikasi keorganisasian. Kegiatan dalam penelitian ini dapat dipahami sebagai kajian mendalam dan menyeluruh tentang pelaksanaan sistem komunikasi keorganisasian yang betujuan untuk meningkatkan efektivitas Organisasi WALHI Yogyakarta. "Membangun dan memelihara sistem komunikasi yang efektif tersebut adalah fungsi pokok eksekutif perusahaan atau organisasi" (Hardjana, 2000:15). Untuk dapat mengetahui apakah kegiatan atau program komunikasi yang dilakukannya itu efektif atau tidak serta untuk mengukur kinerja dan kualitas eksekutif, pejabat dan staf komunikasi maka eksekutif harus melakukan audit komunikasi atas proses-proses komunikasi yang terjadi dalam organisasinya secara berkala.

Dengan melakukan audit komunikasi, segala hambatan komunikasi dan gangguan yang menyebabkan macetnya aliran informasi dan peluang yang terlewat dapat diketahui sehingga diperoleh cara yang dapat meningkatkan dampak yang dikehendaki sehingga organisasi atau perusahaan dapat mempertahankan hidup bahkan kesuksesannya ditengah persaingan global yang makin keras. Audit komunikasi ini juga dapat dijadikan sebagai salah satu jenis penelitian dalam tahap fact finding kegiatan atau manajemen kehumasan.

Komunikasi Organisasi (Organizational Communication) mencakup komunikasi yang terjadi didalam dan diantara lingkungan yang besar dan luas.Jenis komunikasi ini sangat bervariasi karena komunikasi organisasi juga meliputi komunikasi interpersonal (percakapan antara atasan dan bawahan), kesempatan berbicara didepan publik (presentasi yang dilakukan oleh para eksekutif dalam perusahaan), kelompok kecil (kelompok kerja yang mempersiapkan laporan), dan komunikasi dengan menggunakan media (memo internal, e-mail, dan konferensi jarak jauh). Suatu proses pembuatan dan pertukaran pesan-pesan dalam suatu jaringan hubungan yang saling terkait untuk mengatasi atau berurusan dengan ketidakpastian lingkungan. (Golhaber, 1993: 15)

Tujuan komunikasi dalam proses organisasi tentu dalam rangka membentuk saling pengertian (mutual undestanding) Pendek kata agar terjadi penyetaraan dalam kerangka referensi, maupun dalam pengalaman. (Effendy, 2009: 9)

Efektivitas yaitu keberhasilan suatu usaha atau tindakan. Komunikasi organisasi dapat dikatakan efektif, jika melakukan kegiatan dengan benar. Komunikasi yang paling efektif adalah penting bagi semua organisasi. Oleh karena itu, para pimpinan organisasi dan para komunikator dalam organisasi perlu memahami dan menyempurnakan kemampuan komunikasi mereka. Barnard (1938) menegaskan bahwa fungsi pokok seorang eksekutif adalah " membangun dan memelihara sistem komunikasi yang efektif". (Hardjana, 2000:1)

Efektivitas komunikasi adalah yang selalu ingin dicapai dalam setiap kegiatan 
komunikasi terutama di dalam organisasi. Secara sederhana komunikasi dinilai efektif bila rangsangan yang disampaikan dan yang dimaksudkan oleh pengirim atau sumber berkaitan erat dengan rangsangan yang ditangkap dan dipahami oleh penerima. Komunikasi yang efektif dapat dilakukan dengan menggunakan teknik mencari bidang-bidang yang sama atau teknik kepentingan bersama. Ukuran bagi komunikasi yang efektif adalah pada segi pemahaman, kesenangan, pengaruh pada sikap, hubungan yang semakin baik dan tindakan.

Dalam proses pelaksanaan komunikasi ditemui hambatan-hambatan komunikasi, sehingga komunikasi menjadi tidak efektif. Komunikasi yang tidak efektif tersebut dapat disebabkan berbagai macam hambatan baik secara manusiawi mauapun secara teknis. Bentuk-bentuk hambatan tersebut dapat diklasifikasikan ke dalam empat kategori, pertama dalam diri pribadi, antar pribadi, organisional, dan teknologis. Penelitian ini bertujuan menganalisis proses pelaksanaan audit komunikasi organisasi pada Organisasi WALHI Yogyakarta terhadap peningkatan sistem organisasi untuk meningkatkan efektivitas organisasi. Penelitian ini menggunakan teori informasi organisasi.

Karl Weick mengembangkan sebuah pendekatan untuk proses organisasi mengumpulkan, mengelola, dan menggunakan informasi yang mereka terima. Weick menekankan pada proses mengorganisasikan. Dengan demikian, fokus utamanya adalah pada pertukaran informasi yang terjadi didalam organisasi dan bagaimana anggota mengambil langkah untuk memahami hal ini". (West dan Tuner, 2008: 335)

Konsep Kunci dan Mengkonseptualisasikan Informasi Teori informasi dan organisasi Weick berisi sejumlah konsep kunci yang sangat penting dalam memahami teori ini.Konsep-konsep ini mencakup lingkungan informasi, ketidakjelasan informasi, aturan, dan siklus. Tiap proses ini akan dijelaskan secara mendetail. Lingkungan Informasi. Jumlah total lingkungan informasi adalah konsep inti dalam memahami bagaimana organisasi dibentuk dan juga bagaimana mereka memproses informasi. Organisasi mempunyai dua tugas utama yang harus dilaksanakan untuk mengelola dengan sukses berbagai informasi:1. Mereka harus menginterprestasikan informasi eksternal yang ada di dalam lingkungan informasi 2. Mereka harus mengordinasikan informasi untuk membuatnya bermakna bagi anggota-anggota organisasi dan tujuan organisasi.Ketidakjelasan Informasi seperti sudah dinyatakan sebelumnya, organisasi tergantung pada dan menerima informasi dalam jumlah besar.Tantangannya terletak pada kemampuan organisasi untuk memahami informasi yang diterima.

Organisasi menerima informasi dari berbagai sumber.Mereka harus mengartikan informasi dan menentukan apakah informasi tersebuat dapat dipahami, orang atau departemen mana yang paling mampu untuk mengurus informasi ini, dan apakah berbagai departemen membutuhkan informasi ini untuk menyelesaikan tujuannya. Weick memberikan contoh mengenai aturan yang dapatmenyebabkan suatu organisasi untuk memilih satu siklus informasi atau umpan balik dibandingkan yang lain untuk mengurangi ketidakjelasan pesan.

Dalam penelitian ini, Organisasi WALHI Yogyakarta menerima informasi dari berbagai sumber dari pihak internal maupun eksternal berkaitan dengan teori informasi organisasi yang dapat dijadikan analisis untuk melakukan audit komunikasi organisasi. Sumber informasi dari pihak internal di Organisasi WALHI Yogyakarta dapat berupa pertukaran pendapat atau opini antar pejabat disaat melakukan sosialisasi, pesan apa yang 
diterima dan menentukan siapa yang harus menerima informasi tersebut demi mencapai tujuan organisasi, mediamedia yang digunakan oleh organisasi untuk menyelesaikan tujuan mereka, serta iklim komunikasi yang ada di organisasi tersebut. Sumber informasi dari pihak eksternal di Organisasi WALHI Yogyakarta dapat berupa informasi dari pemerintah dan instansi-instansi yang terkait.

\section{Metode Penelitian}

Penelitian ini bersifat deskriptif kualitatif. Penelitian ini tidak menjelaskan hubungan, tidak mengkaji hipotesis atau membuat prediksi karena lebih memfokuskan pada analisisyang dilakukan di WALHI Yogyakarta sebagai sistem komunikasi organisasi yang mempunyai tujuan untuk meningkatkan efektivitas organisasi.

Melalui audit komunikasi dengan metode wawancara tatap muka, observasi, dan studi dokumen. Peneliti menjabarkan mengenai jenis komunikasi, tujuan komunikasi,serta hambatan yang terjadi dalam komunikasi di Organisasi WALHI Yogyakarta. Hasil penelitian menunjukkan bahwa media komunikasi yang digunakan beraneka macam yang disesuaikan dengan tujuan komunikasi. Terdapat hambatan-hambatan yang terjadidalam komunikasi ini, yaitu hambatan lingkungan, sumber daya manusia, dan tugas sertatanggung jawab individu.

Peneliti melakukan wawancara tatap muka dengan Direktur Eksekutif dan Eksekutif Daerah dalam bidang Kesekretariatan, Penguatan Kelembagaan dan Advokasi Kawasan Organisasi WALHI Yogyakarta serta melakukan observasi (pengamatan langsung) di lapangan untuk memperoleh datadata yang digunakan untuk penelitian. Dengan melakukan wawancara dan observasi, merupakan cara peneliti untuk mengetahui bagaimana cara meningkatkan efektivitas organisasi melalui audit komunikasi.

\section{Hasil Penelitian dan Pembahasan}

Berdasarkan proses pelaksanaan audit komunikasi organisasi serta kendala-kendala atau hambatanhambatan yang sering terjadi di dalam Organisasi WALHI Yogyakarta, dapat dijelaskan bahwa besarnya informasi yang ada mempunyai sumbangan yang cukup banyak dalam mendukung kinerja divisi staf organisasi.

Teori Informasi Organisasi membantu mengarahkan penulis melakukan pembahasan di Teori ini menyatakan bahwa untuk mengelola informasi dalam jumlah besar adalah sebuah tantangan bagi khalayak organisasi. Organisasi tidak hanya dihadapkan pada tugas untuk mengartikan pesan yang diterima, tetapi juga menghadapi tantangan untuk menentukan siapa yang harus menerima informasi tersebut demi mencapai tujuan organisasi.

Di dalam teori ini dijelaskan bahwa organisasi menerima informasi dari berbagai sumber. Mereka harus mengartikan informasi dan menentukan apakah informasi tersebut dapat dipahami, orang atau departemen mana yang paling mampu untuk mengurus informasi ini, dan apakah berbagai departemen membutuhkan informasi ini untuk menyelesaikan tujuannya. Organisasi adalah sebuah sistem yang membutuhkan orang-orang untuk menjalankan fungsi organisasi tersebut. Sebagai sebuah organisasi yang berpengaruh di dalam sebuah lingkungan, WALHI pasti menjalankan proses audit komunikasi untuk mengevaluasi sistem komunikasi internal maupun eksternal komunikasi organisasi.

Komunikasi yang terjadi pada Organisasi WALHI Yogyakarta menitik beratkan pada penempatan komunikasi 
Tabel 1. Hasil Audit Komunikasi Dewan Daerah dan Direktur Eksekutif Organisasi WALHI Yogyakarta 2015

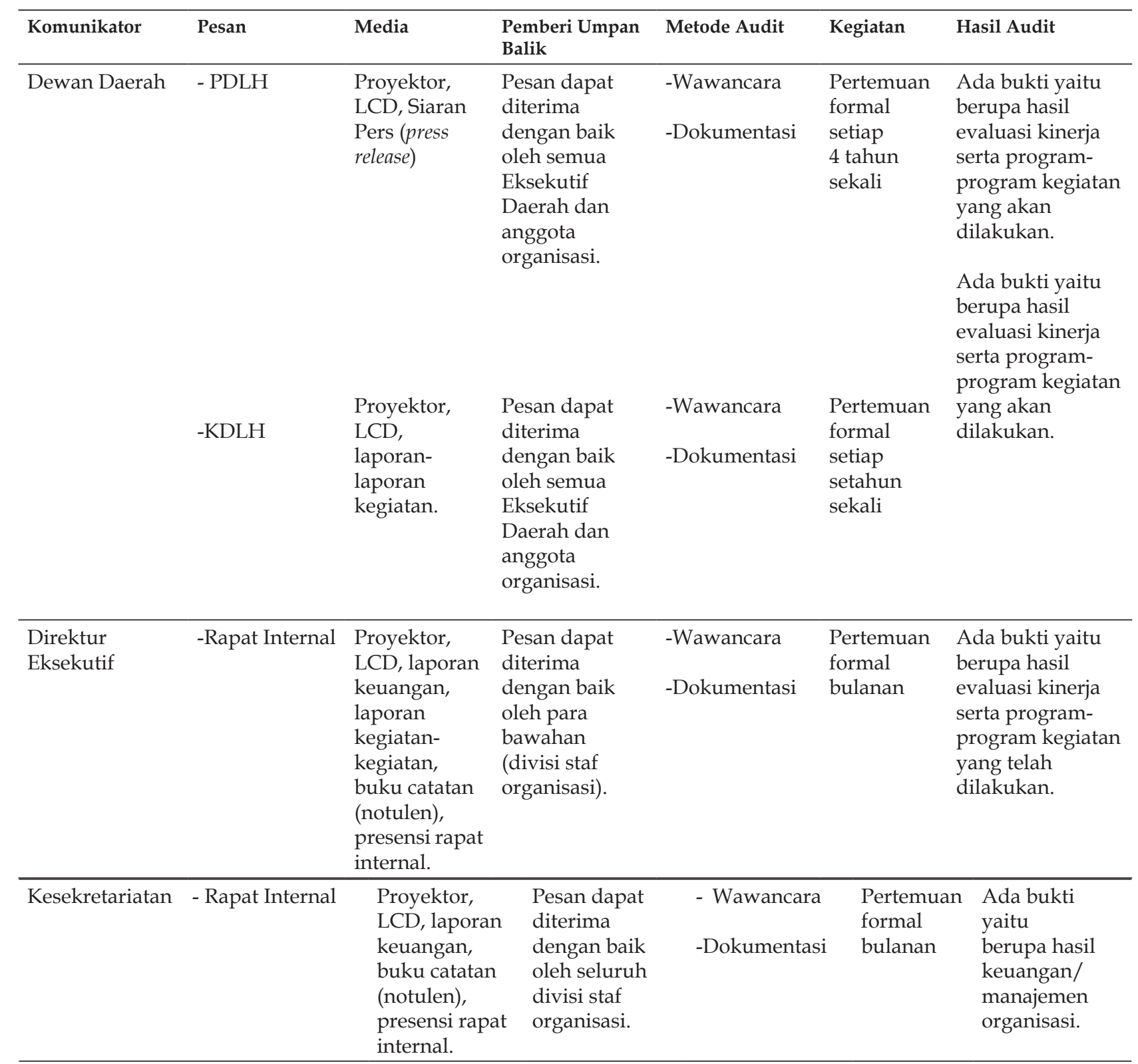

(Sumber: Hasil olah data lapangan 2015)

secaravertikalmaupunhorizontal, dimana peranan komunikasi akan mempengaruhi kinerja divisi staf organisasi. Penggunaan teknologi komunikasi juga membantu meningkatkan kinerja dari para divisi staf organsiasi. Telepon, sms, dan sistem jaringan komputer akan mempermudah akses mendapatkan informasi yang diinginkan dan disosialisasikan kepada anggota organisasi serta masyarakat atau publik. Berdasarkan teori dari Myron Emmanuellyang menyatakan bahwapada dasarnya, audit komunikasi merupakan kajian yang menyeluruh tentang struktur, arus, dan praktek-praktek komunikasi dalam suatu organisasi, baik itu organisasi kecil atau besar, organisasi usaha atau nirlaba, dan swasta atau publik. Suatu audit komunikasi diharapkan dapat mengatasi kemacetankemacetan informasi, hambatanhambatan terhadap komunikasi yang efektif, dan peluang-peluang yang telah disia-siakan (Hardjana, 2000: 12). 
Tabel 2. Hasil Audit Komunikasi Kesekertariatan Organisasi WALHI Yogyakarta 2015

\begin{tabular}{|c|c|c|c|c|c|c|}
\hline Komunikator & Pesan & Media & $\begin{array}{c}\text { Pemberi } \\
\text { Umpan Balik }\end{array}$ & Metode Audit & Kegiatan & Hasil Audit \\
\hline \multirow[t]{5}{*}{$\begin{array}{l}\text { Advokasi } \\
\text { Kawasan }\end{array}$} & $\begin{array}{l}\text { - Pendidikan } \\
\text { Lingkungan }\end{array}$ & $\begin{array}{l}\text { Siaran Pers } \\
\text { (press release), } \\
\text { Media Cetak } \\
\text { (Koran) Media } \\
\text { elektronik (TV } \\
\text { lokal, radio, } \\
\text { koran online). }\end{array}$ & $\begin{array}{l}\text { Pesan dapat } \\
\text { diterima dengan } \\
\text { baik oleh } \\
\text { masyarakatatau } \\
\text { publik. }\end{array}$ & $\begin{array}{l}\text {-Wawancara } \\
\text {-Dokumentasi } \\
\text { - Observasi }\end{array}$ & Sosialisasi & $\begin{array}{l}\text { Ada bukti } \\
\text { yaitu berupa } \\
\text { masyarakat } \\
\text { semakin } \\
\text { tahu tentang } \\
\text { kasus-kasus } \\
\text { yang terjadi di } \\
\text { lingkungan. }\end{array}$ \\
\hline & $\begin{array}{l}\text { - Kampanye } \\
\text { Lingkungan }\end{array}$ & $\begin{array}{l}\text { Siaran Pers } \\
\text { (press release), } \\
\text { Media Cetak } \\
\text { (Koran) Media } \\
\text { elektronik (TV } \\
\text { lokal, radio, } \\
\text { koran online). }\end{array}$ & $\begin{array}{l}\text { Pesan dapat } \\
\text { diterima dengan } \\
\text { baik oleh } \\
\text { masyarakat atau } \\
\text { publik. }\end{array}$ & $\begin{array}{l}\text {-Wawancara } \\
\text {-Dokumentasi } \\
\text { - Observasi }\end{array}$ & Sosialisasi & $\begin{array}{l}\text { Ada bukti yaitu } \\
\text { berupa } \\
\text { masyarakat } \\
\text { ikut berpartisi- } \\
\text { pasi dalam } \\
\text { melakuka } \\
\text { penyelama- } \\
\text { tan lingkungan. }\end{array}$ \\
\hline & $\begin{array}{l}\text { - Pendampingan } \\
\text { masyarakat } \\
\text { dalam } \\
\text { menangani kasus }\end{array}$ & $\begin{array}{l}\text { Siaran Pers } \\
\text { (press release), } \\
\text { Media Cetak } \\
\text { (Koran) Media } \\
\text { elektronik (TV } \\
\text { lokal, radio, } \\
\text { koran online). }\end{array}$ & $\begin{array}{l}\text { Pesan dapat } \\
\text { diterima dengan } \\
\text { baik oleh } \\
\text { masyarakat atau } \\
\text { publik. }\end{array}$ & $\begin{array}{l}\text {-Wawancara } \\
\text {-Dokumentasi } \\
\text { - Observasi }\end{array}$ & Sosialisasi & $\begin{array}{l}\text { Ada bukti } \\
\text { yaitu berupa } \\
\text { penyelesai- } \\
\text { an suatu kasus } \\
\text { dari isu-isu } \\
\text { tertentu yang } \\
\text { berkem- } \\
\text { bang di } \\
\text { masyarakat. }\end{array}$ \\
\hline & $\begin{array}{l}\text { - Penanggulangan } \\
\text { bencana }\end{array}$ & $\begin{array}{l}\text { Media Cetak } \\
\text { (Koran) Media } \\
\text { elektronik (TV } \\
\text { lokal, radio, } \\
\text { Koran online) }\end{array}$ & $\begin{array}{l}\text { Pesan dapat } \\
\text { diterima dengan } \\
\text { baik oleh } \\
\text { masyarakat atau } \\
\text { publik. }\end{array}$ & $\begin{array}{l}\text {-Wawancara } \\
\text {-Dokumentasi } \\
\text { - Observasi }\end{array}$ & Sosialisasi & $\begin{array}{l}\text { Ada bukti } \\
\text { yaitu berupa } \\
\text { kegiatan- } \\
\text { kegiatan } \\
\text { penanggu- } \\
\text { langan bencana } \\
\text { di daerah } \\
\text { kawasan- } \\
\text { kawasan } \\
\text { tertentu. }\end{array}$ \\
\hline & -Rapat Internal & $\begin{array}{l}\text { Proyektor, } \\
\text { LCD, laporan } \\
\text { kegiatan } \\
\text { seperti : } \\
\text { kampanye, } \\
\text { penanggu- } \\
\text { langan } \\
\text { bencana, } \\
\text { investigasi } \\
\text { dan respon } \\
\text { isu (Advokasi } \\
\text { Kawasan), } \\
\text { buku catatan } \\
\text { (notulen), } \\
\text { presensi rapat } \\
\text { internal. }\end{array}$ & $\begin{array}{l}\text { Pesan dapat } \\
\text { diterima dengan } \\
\text { baik oleh } \\
\text { seluruh divisi } \\
\text { staf organisasi. }\end{array}$ & $\begin{array}{l}\text { - Wawancara } \\
\text { - Dokumentasi }\end{array}$ & $\begin{array}{l}\text { Pertemuan } \\
\text { formal } \\
\text { bulanan }\end{array}$ & $\begin{array}{l}\text { Ada bukti yaitu } \\
\text { berupa laporan } \\
\text { kegiatan- } \\
\text { kegiatan } \\
\text { penanggu- } \\
\text { langan bencana } \\
\text { di daerah } \\
\text { kawasan- } \\
\text { kawasan } \\
\text { tertentu. }\end{array}$ \\
\hline
\end{tabular}

Pada penelitian ini menemukan kendala-kendala atau hambatanhambatan yang terjadi yaitu kurangnya penyediaan media penunjang inventaris seperti laptop atau komputer untuk menunjang kinerja para divisi staf organisasi. Saat penelitian dilakukan, mereka masih menggunakan komputer atau laptop pribadi sebagai alat untuk menyelesaikan pekerjaan mereka. Hal ini 
Tabel 3. Hasil Audit Komunikasi Kelembagaan Organisasi WALHI Yogyakarta 2015

\begin{tabular}{|c|c|c|c|c|c|c|}
\hline Komuni-kator & Pesan & Media & $\begin{array}{c}\text { Pemberi } \\
\text { Umpan } \\
\text { Balik }\end{array}$ & $\begin{array}{l}\text { Metode } \\
\text { Audit }\end{array}$ & Kegiatan & Hasil Audit \\
\hline \multirow[t]{3}{*}{ Kelembagaan } & - Rapat Internal & $\begin{array}{l}\text { Proyektor, } \\
\text { LCD, laporan } \\
\text { kegiatan- } \\
\text { kegiatan, } \\
\text { buku catatan } \\
\text { (notulen), } \\
\text { presensi rapat } \\
\text { internal. }\end{array}$ & $\begin{array}{l}\text { Pesan dapat } \\
\text { diterima } \\
\text { dengan baik } \\
\text { oleh seluruh } \\
\text { divisi staf } \\
\text { organisasi. }\end{array}$ & $\begin{array}{l}\text { - Wawancara } \\
\text {-Dokumentasi }\end{array}$ & $\begin{array}{l}\text { Pertemuan } \\
\text { formal } \\
\text { bulanan }\end{array}$ & $\begin{array}{l}\text { Ada bukti } \\
\text { yaitu berupa } \\
\text { laporan } \\
\text { kinerja } \\
\text { yang telah } \\
\text { dilakukan. }\end{array}$ \\
\hline & - Riset dan kajian & $\begin{array}{l}\text { Laporan- } \\
\text { laporan hasil } \\
\text { riset dan } \\
\text { kajian, buletin. }\end{array}$ & $\begin{array}{l}\text { Pesan dapat } \\
\text { diterima } \\
\text { dengan } \\
\text { baik oleh } \\
\text { masyarakat } \\
\text { kawawan } \\
\text { tertentu. }\end{array}$ & $\begin{array}{l}\text {-Wawancara } \\
\text {-Dokumentasi } \\
\text { - Observasi }\end{array}$ & $\begin{array}{l}\text { Workshop } \\
\text { di Kawasan } \\
\text { tertentu, } \\
\text { diskusi, } \\
\text { penelitian } \\
\text { tentang } \\
\text { kelestarian } \\
\text { lingkungan. }\end{array}$ & $\begin{array}{l}\text { Ada bukti } \\
\text { yaitu berupa } \\
\text { program- } \\
\text { program } \\
\text { kegiatan } \\
\text { yang sudah } \\
\text { dilakukan } \\
\text { di kawasan } \\
\text { tertentu. }\end{array}$ \\
\hline & - Dana publik & $\begin{array}{l}\text { Media } \\
\text { elektronik } \\
\text { (telepon, sms } \\
\text { hotline, email, } \\
\text { facebook, } \\
\text { twitter. }\end{array}$ & $\begin{array}{l}\text { Pesan dapat } \\
\text { diterima } \\
\text { dengan } \\
\text { baik oleh } \\
\text { masyarakat } \\
\text { atau publik. }\end{array}$ & $\begin{array}{l}\text {-Wawancara } \\
\text {-Dokumentasi } \\
\text { - Observasi }\end{array}$ & $\begin{array}{l}\text { Pengga- } \\
\text { langan dana } \\
\text { melalui } \\
\text { cara online } \\
\text { maupun } \\
\text { offline }\end{array}$ & $\begin{array}{l}\text { Ada bukti } \\
\text { yaitu berupa } \\
\text { donasi } \\
\text { yang telah } \\
\text { terkumpul } \\
\text { perolehan } \\
\text { dari } \\
\text { individu } \\
\text { atau } \\
\text { komunitas } \\
\text { masyarakat. }\end{array}$ \\
\hline
\end{tabular}

(Sumber: Hasil olah data lapangan 2015)

terjadi karena keterbatasan dana untuk menyedikan alat-alat inventaris tersebut. Organisasi masih mengupayakan untuk menyediakan alat-alat inventaris dan berusaha memperbaiki kondisi fisik perlengkapan yang ada di dalam organisasi. Keterbatasan SDM yang ada menyebabkan terhambatnya penerbitan buletin organisasi yang sebelumnya sudah diterbitkan secara rutin tiap bulan.

Organisasi WALHI Yogyakarta memang tidak memiliki bagian humas, seperti pada umumnya perusahaan maupun organisasi lainnya. Bagian tersebut dianggap tidak terlalu penting bagi organisasi karena organisasi telah mempunyai divisi staf yaitu Eksekutif Daerah bagian Advokasi Kawasan.
Eksekutif Daerah tersebut merupakan divisi staf yang sering berhubungan langsung dengan masyarakat atau publik. Kinerja yang dilakukan divisi staf tersebut meliputi pendidikan lingkungan, kampanye lingkungan, pendampingan masyarakat dalam menangani kasus, dan penanggulangan bencana. Setelah melakukan penelitian mengenai audit komunikasi organisasi, di dalam organisasi ini tidak terdapat kemacetan informasi dari berbagai sumber di internal maupuan eksternal organisasi yang disampaikan secara vertikal maupun horizontal, karena pihak organisasi selalu menginformasikan ke bagian-bagian tertentu yang harus mendapatkan informasi tersebut. 


\section{Simpulan}

Saat melakukan proses Audit Komunikasi Organisasi WALHI Yogyakarta, peneliti menemukan beberapa hambatan. Pihak organisasi kadangkadang belum bisa memastikan kapan jadwal untuk wawancara dengan narasumber dikarenakan narasumber yang diwawancarai masih sibuk dengan urusan organisasi atau kegiatan-kegiatan organisasi yang sedang berlangsung. Hambatan tersebut dapat teratasi setelah memperoleh komitmen untuk melaksanakan audit komunikasi.

Pada umumnya proses komunikasi di Organisasi WALHI Yogyakarta berjalan cukup lancar dengan memakai sistem vertical - horizontal, tetapi perlu ada penanganan kendala atau hambatanhambatan yang terjadi di dalam organisasi. Hasil Audit Komunikasi Organisasi dibuktikan adanya beberapa faktor yaitu; (1). Muatan Informasi. Berdasarkan muatan informasi yang terjadi didalam Organisasi WALHI Yogyakarta berlangsung cukup baik, informasi tersebut berasal dari pihak internal maupun eksternal organisasi, dari media komunikasi tertulis/cetak dan media komunikasi elektronik. Keterbukaan antar divisi staf mempunyai pengaruh yang besar terhadap informasi yang masuk ke semua anggota organisasi, selain itu perhatian antar divisi staf organisasi menciptakan suasana yang kondusif dalam proses penyampaian informasi. Dukungan media komunikasi tertulis dan elektronik sangat menunjang mereka dalam hal efisiensi waktu, penggunaan teknologi komunikasi seperti telepon, sms, dan sistem jaringan komputer sangat membantu dalam proses penyampaian informasi antar divisi staf dan anggota organisasi. (2) Proses komunikasi/kegiatan-kegiatan komunikasi. Secara umum proses atau kegiatan-kegiatan komunikasi mempunyai peran yang besar dalam membentuk suasana komunikasi yang efektif dalam mendukung kinerja divisi staf organisasi. Keterbukaan mereka dalam berkomunikasi sehingga dapat meminimalisir hambatan-hambatan yang ada dalam melaksanakan pekerjaan. Tidak adanya perbedaan kedudukan meskipun dilihat dari segi usia mereka, usia atasan lebih muda dibanding usia salah satu dari bawahan, atasan berusaha untuk mempercayai dan mengandalkan bawahannya untuk menyelesaikan tugas-tugas, sehingga dengan suasana kerja seperti itu dapat lebih mempererat hubungan antara atasan dengan bawahan dan lebih meningkatkan kinerja para divisi staf organisasi. (3) Pola-Pola Komunikasi.

Pola komunikasi yang diterapkan di Organisasi WALHI Yogyakarta adalah pola komunikasi dua arah artinya komunikator maupun komunikan dalam hal ini adalah atasan terhadap bawahan maupun sebaliknya. Hal ini didukung adanya pertemuan formal yang bersifat rutin guna membahas setiap kebijakan baru maupun tentang program-program ke depan dan pertemuan non formal seperti diskusi yang dilakukan antar kedua divisi staf organisasi. (4) Umpan Balik. Kegiatan-kegiatan yang telah dilakukan oleh Organisasi WALHI Yogyakarta selalu mendapatkan umpan balik dengan baik dari berbagai pihak yang bersangkutan.Mereka memeriksa hasil komunikasi secara periodik, misalnya setidaknya setiap 3 bulan sekali hasil komunikasi yang telah dilakukan.Kegiatankegiatan tersebut selalu mendapatkan hasil/bukti-bukti yang terkadang bisa didokumnetasikan.Rekomendasi kegiatan yang dibuat berdasarkan hasil riset yang telah dilakukan dan umpan balik selalu ditindaklanjuti atau dilaksanakan.

Pada dasarnya sistem komunikasi Organisasi WALHI Yogyakarta sudah berjalan dengan cukup baik, adapun 
kendala-kendala yang ada bersifat teknis artinya komunikasi secara vertikal, horizontal, pengggunaan media tertulis dan media elektronik sebagai penunjang kelancaran berkomunikasi.

Implikasi dari penelitian ini bahwa setiap organisasi perlu dilakukan audit komunikasi agar proses komunikasi yang terjadi dalam organisasi dapat dievaluasi dan persoalan-persoalan komunikasi yang ada dapat segera diatasi. Organisasi yang memiliki arus informasi dan komunikasi secara lancar dapat meningkatkan kinerja dan kesejahteraan anggota-anggota organisasi tersebut. Audit komunikasi sebaiknya dilakukan secara periodik.

\section{Daftar Pustaka}

Goldhaber, G. M. \& Donald P. R. (1979). Auditing organizational communication systems: the ICA communication audit, USA: Kendall/Hunt Publishing Company.

Hardjana, Andre. (2000). Audit Komunikasi. Grasindo: Jakarta.

Moleong, L.J. (2004). Metodologi Penelitian Kualitatif. Remaja Karya: Bandung.

Pace, R. Wayne dan Don F. Faules. (2006). Komunikasi Organisasi. Remaja Rosdakarya: Bandung.

Panghegar, Stephani Firmawan. (2003). Audit Komunikasi Organisasi Horisontal Departemen Front Office Singgasana Hotel Surabaya. Surabaya.

Raco, J. R. (2010). Metode Penelitian Kualitatif. Grasindo: Jakarta.

Sulistiowati. (2007). Audit Komunikasi Direktorat Kantor Pusat PT. Pembangkit Jawa-Bali Surabaya dalam Downward Communication. (Tesis diterbitkan) Universitas Kristen Petra: Surabaya.
Suprapto, Tommy. (2009) Pengantar Teori dan Manajemen Komunikasi. MedPress: Yogyakarta.

Susanto, Dewi Suryani. (2013) Downward Communication di PT. Commonwealth Life Cabang Surabaya. Surabaya.

Wahab, Abdul Aziz. (2008). Anatomi Organisasi dan Kepemimpinan Pendidikan. Alfabeta: Jakarta.

Wiryanto. (2004). Pengantar Ilmu Komunikasi. Grasindo: Jakarta.

West, Richard dan Lynn H. Turner. (2008) Pengantar Teori Komunikasi Analisis dan Aplikasi. Salemba Humanika: Jakarta.

\section{Internet}

https://heruteddyliberty.files.wordpress. com/2013/10/proses-komunikasi. png diakses pada tanggal 22 Desember 2014

http:// pemerintah.net/keterbukaaninformasi-publik-pemerintah/ Diakses pada tanggal 30 September 2014

http://www.artikellingkunganhidup. com/pengertian-lingkungan-hidup. html)Diakses pada tanggal 30 September 2014

http:/ / www.hukumonline.com / pusatdata/detail/28065/nprt/1011/ uu-no-14-tahun-2008-keterbukaaninformasi-publik diakses pada tanggal 30 September 2014

http:/ / www.lspr.edu/pritakemalgani/ audit-komunikasi/ diakses pada tanggal 15 Oktober 2014

http://www.walhi-jogja.or.id/ Diakses pada tanggal 30 September 2014 